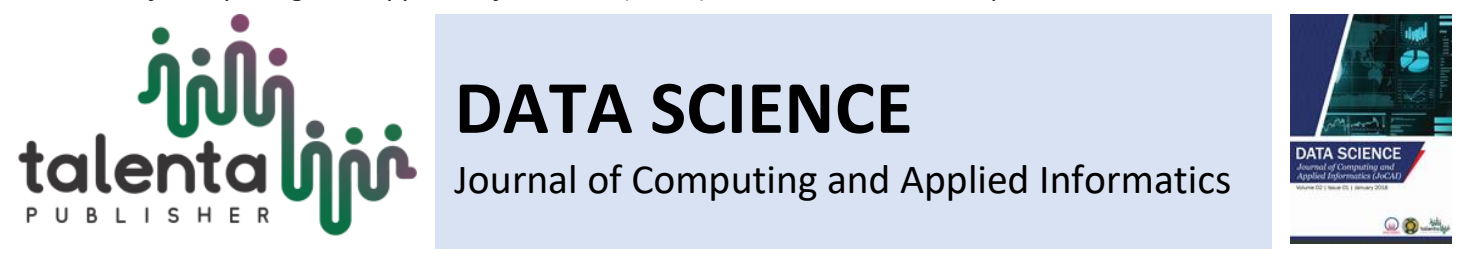

\title{
Usability Engineering and Evaluation of Usability In District Tourism And Culture Information Systems
}

\author{
Wasis Haryono \\ Pamulang University, Information Technology, Indonesia
}

\begin{abstract}
So far, the potential of natural resources has not been fully managed by the government or the community. For that we need a mature tourist object planning either by visitors or by developers. Communities need information provided on a mobile basis that can be accessed anywhere. This information is inseparable from the role of technology that supports so that applications can be used by tourists who want to visit either in the form of an address or location. Applications that are worthy of use are applications that have been tested usefulness or called usability. To test a system requires a questionnaire which one of them is SUMI (Software Usability Measurement Inventory). This study uses a method adopted from usability engineering lifecycle. The results of this study in the form of assessment with several criteria, so the application is feasible to use.
\end{abstract}

Keyword: Tourism Object, Information, Usability, SUMI, Usability Engineering Lifecycle

\begin{abstract}
Abstrak. Selama ini potensi sumber daya alam belum sepenuhnya dikelola oleh pemerintah ataupun masyarakat. Untuk itu diperlukan suatu perencanaan objek wisata yang matang baik oleh pengunjung maupun oleh pengembang. Masyarakat memerlukan informasi yang disediakan berbasis mobile yang bisa diakses dimana saja. Informasi ini tidak terlepas dari peran teknologi yang menunjang sehingga aplikasi tersebut bisa digunakan oleh para wisatawan yang hendak berkunjung baik berupa alamat atau lokasi. Aplikasi yang layak digunakan adalah aplikasi yang sudah diuji kebergunaannya atau disebut dengan usability. Untuk menguji sebuah sistem memerlukan kuesioner yang salah satunya yaitu SUMI (Software Usability Measurement Inventory). Penelitian ini menggunakan metode yang diadopsi dari usability engineering lifecycle. Hasil penelitian ini berupa penilaian dengan beberapa kriteria, sehingga aplikasi tersebut layak digunakan.
\end{abstract}

Kata Kunci: Tourism object, information, Usability, SUMI, usability engineering lifecycle

Received 27 May 2019| Revised 12 July 2019| Accepted 12 July 2019

\section{Introduction}

So far, the potential of natural resources that can be managed and developed and utilized by local communities is through fisheries and tourism activities [1]. So that it is necessary to develop tourist sites that are full of careful planning accompanied by accurate data which is one of the references for tourists to determine their destination and gain satisfaction in traveling [2].

\footnotetext{
*Corresponding author at: Pamulang University, Information Technology, Indonesia
} 
Besides that, information about tourist objects requires the availability of the right information both through addresses, costs and attractions that are not yet known to the public [3]. Therefore, information technology plays an important role in optimizing tourism growth [4]. To overcome the need for information, a system is needed to provide all the information needed [5]. The key to an information system that is well received by society is the usability or usability of an information system. The formulation of the problem in this study is the need to use usability engineering and usability evaluation on a system, making it easier for users to use an application Usability is very necessary to evaluate the system to be designed [6]. Usability is then evaluated using several questionnaires, for example the SUMI (Software Usability Measurement Inventory) questionnaire. So the title that I raised in this study was "Usability Engineering and Usability Evaluation in the Bogor Regency Tourism and Culture Information System".

\section{Objectives of the Study}

This study aimed to:

1. Discuss the feasibility of a system that will be used by users.

2. The researcher uses a method adopted from the Usability Engineering Life Cycle method [7].

3. Usability evaluation questionnaire using SUMI questionnaire.

4. The results of the study are in the form of a measure that can be used as a benchmark for the use of a system.

\section{Teoritical Framework}

\subsection{Related Research}

The study, entitled Usability Testing to Improve the Mobile Application Interface, discusses usability testing in children's applications by using the field observation method by observing users how they use the application. The components tested are in the form of components of effectiveness, efficiency and satisfaction. The test results show that the direct observation method in children can increase the usability value of M-Breakfast Nutrition from $78.4 \%$ to $91.1 \%$ so that the application is expected to be in accordance with the objectives so that it can be accepted by the user [8].

The study entitled Application of Usability Method Testing on Prabumulih City Government Website Evaluation, discusses how far the mistakes made by users and measuring the contents of the website are based on the implementation of regional government web sites issued by the Ministry of Communication of the Republic of Indonesia in 2003. The results of this study also show that $100 \%$ learnability, efficiency $66.66 \%$, memorability $58.33 \%$, satisfaction $53.33 \%$ that can be used by users [9]. 
The study entitled Measurement of Usability of Financial Information Systems Case Study: Duta Wacana Internal Transaction (DuWIT), discusses how much the level of understanding and difficulty of users in using the transaction system through the DuWIT application. The results of this study indicate usability above $72 \%$ so that this application is declared user friendly [10].

\subsection{Usability}

Usability is defined as a quality attribute that assesses how easily the user interface is used, thus enabling the user to develop tasks clearly, transparently and useful [11]. Usability is the interaction between the media and the user [12]. Planning The initial stage of the system uses usability and interfaces for users [13]. Usability can be seen as one of the criteria to ensure the level of good and bad of a product [14]. Problems in usability are caused by a lack of knowledge that is often identified when first using the system [15]. Usability of software products has become a key factor in software quality [16]. Usability is one of the most important parts to know the characteristics of the quality of a system [17].

\subsection{Usability Engineering}

Usability engineering is a discipline that provides structured methods to achieve usability in user interface design during product development [7]. The stages of usability engineering are:

a. User identification, that is before designing the interface, the most important thing is to understand the use of the system. User identification uses a questionnaire through several questions regarding gender, age, education, etc. [17].

b. Designing the interface appearance, which is designing user activities in the system.

c. Choosing a color that is, color attracts attention because of someone's eyes, if used correctly the display becomes more attractive but if used improperly it can interfere and make the eyes become tired and affect the usability of the system.

\section{Methodology}

This study uses a method adopted from the usability engineering lifecycle [7]. Evaluation using SUMI by paying attention to efficiency, effectiveness and satisfaction and error rate on a system so that the system is feasible to use. 




Figure 1 Research Method

The stages of the research method consist of:

a. Platform Constraints

This stage is used to determine the tourism system development platform Bogor.

b. Design Principles in general

This stage is done using literature studies on user interface design based on the book The

Essential Guide to User Interface Design [17].

c. Conceptual Model

This stage analyzes the user interface design sketches. The interface sketch is done by identifying the main navigation of the system.

d. Screen Design

This stage is done by analyzing the interface design design by paying attention to the standard aspects of the layout of a system.

e. Detail Interface Evaluation

Detailed interface evaluation using the SUMI questionnaire with 10 respondents

\section{Results}

\subsection{Platform Constraints}

Tourism system development platform is mainly used is the Acer Aspire E1-431 device, Intel (R) Celeron Virsion Processor 03.72.02V1.24, 2048MB RAM Memory, 550 GB Hard Drive, VGA Intel (R) HD Graphics, MI 4S XIAOMI Device, Resolution: 4.5 inches (480 x 854 pixels, 4GB Internal Memory, 512MB RAM, 8GB External, Adobe Photoshop CS3, Microsoft Office 
2010, Operating System: Android Jelly bean 4.1.2, Android SDK and ADT Plugin, Android Studio, Windows Operating System 7 Ultimate SP132bit.

\subsection{Design Principles in general}

The design principle is generally used by referring to the book Galitz (2007). The principle consists of:

\section{A. Website Page layout}

Website layout consists of page layout, homepage layout (McGovernt et al 2002). Home page layout is the first page that is seen by the user. This application has a homepage layout and document layout shown in Figure 2.

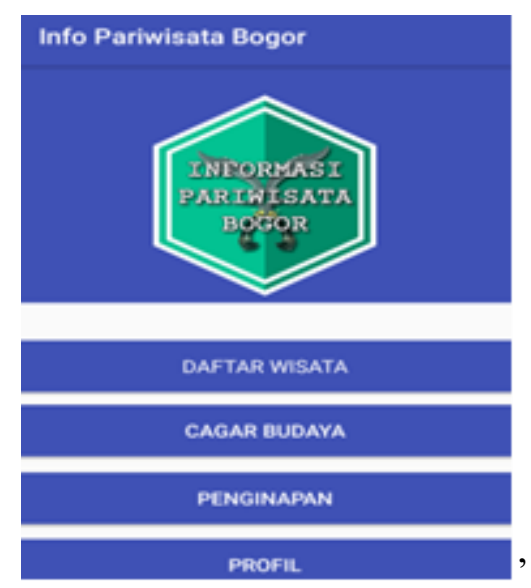

Figure 2 Home page Bogor Tourism Application Layout

\section{B. Scrolling}

Scrolling is used to display all data contents. Because the information provided is quite large, scrolling is needed on the right side of the tip which is marked with an arrow, the scrolling used is the scrolling button type shown in Figure 3.

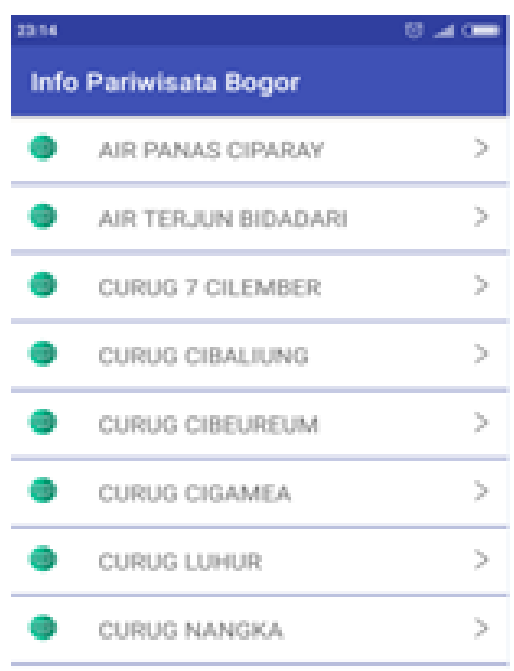

Figure 3 Scroll Button 


\section{C. $\quad$ Message Boxes and Windows Pop-ups}

Message Box is used for messages in certain situations or certain conditions, for example when a user succeeds or fails in uploading or downloading files, or when there is a warning message Contact list Empty. There are no Message Boxes and Pop up Windows in this application.

\section{Color}

The background color of the text used is white and blue. The blue color for the background of the top position of the webpage, the white color for the Masthead section and the text using black the results of the display can be seen in Figure 4.

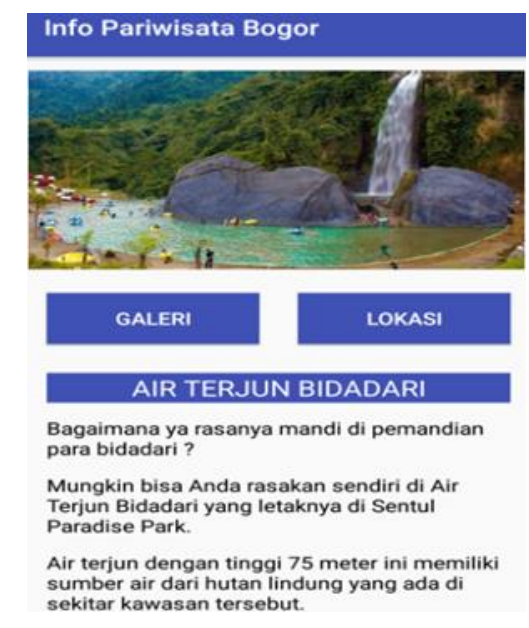

Figure 4 Color display in aplication

\section{E. $\quad \operatorname{Logo}$}

The logo located in Figure 5 is a symbol and characteristic. With the logo makes it easy for users to recognize the institution. This application logo is placed in the middle position on the start page of the application.

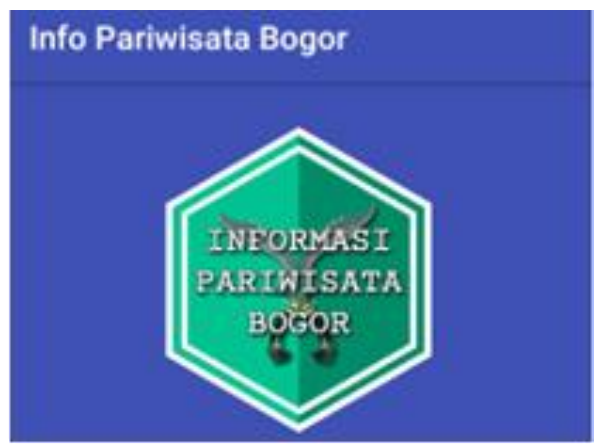

Figure 5 Bogor Tourism Application Logo

\subsection{Conceptual Analysis Design}

Conceptual Design Analysis is done by analyzing the stages of the user using the Tourism application. The stages of using e-learning consist of: 
1. The user opens the main page of the Bogor tourism application

2. After successfully opening the main, the user opens the tour list menu.

3. Choose one tourist list and read information.

4. Users open the Cultural Heritage menu.

5. Choose one of the cultural preservation and read information.

6. The user opens the Lodge menu

7. Choose one of the lodging and read information.

\subsection{Screen Design}

Screen design standards are carried out by analyzing the specific needs of how the e-learning system operates. The contents of the screen design are:

1. Designing headers and footers

2. Handling errors

3. Button

4. Text, Label and column filling

All contents about screen design have been discussed in the General Design Principles

\subsection{Detailed interface evaluation}

This study is usability engineering and usability evaluation in the application of the Bogor Regency Tourism and Culture Information System as many as 10 respondents. This study used a questionnaire adopted from SUMI (Software Usability Measurement Inventory). The purpose of conducting the questionnaire is to evaluate the tourism and cultural information system of Bogor Regency, measure usability and can be a learning medium for instructors for the application to be used. Usability is a context for using applications with measures of effectiveness, efficiency and satisfaction so that they can measure the extent to which an application can be used easily.

Usability which is a context for using applications with measures of effectiveness, efficiency and satisfaction so that they can measure the extent to which an application can be used easily. This questionnaire sheet contains 30 questions about usability of users in accessing the Bogor district tourism and culture information system for 10 respondents. Choice of questions consist (S), don't know (TT) and disagree (TS). where S (agree) multiplied by 4, TT (do not know) multiplied by 2 , and TS (disagree) multiplied by 0 . Results of calculation of Median Effectiveness, Efficiency and satisfaction for Respondents are shown in Table 1, Table 2, Table 3. Results of calculations based on categories found in Table 4.

Table 1 Effectiveness Category

\begin{tabular}{llllllllll}
\hline \multicolumn{10}{c}{ Effectiveness Category } \\
\hline 1 & 2 & 3 & 4 & 5 & 6 & 7 & 8 & 9 & 10 \\
\hline 50 & 80 & 80 & 85 & 85 & 90 & 90 & 100 & 100 & 100 \\
\hline
\end{tabular}


Table 2 Efficiency Category

\begin{tabular}{llllllllll}
\hline \multicolumn{10}{c}{ Efficiency Category } \\
\hline 1 & 2 & 3 & 4 & 5 & 6 & 7 & 8 & 9 & 10 \\
\hline 40 & 50 & 50 & 55 & 75 & 75 & 80 & 80 & 90 & 100 \\
\hline
\end{tabular}

Table 3 Satisfaction category

\begin{tabular}{llllllllll}
\hline \multicolumn{10}{c}{ Satisfaction category } \\
\hline 1 & 2 & 3 & 4 & 5 & 6 & 7 & 8 & 9 & 10 \\
\hline 75 & 80 & 80 & 85 & 85 & 95 & 100 & 100 & 100 & 100 \\
\hline
\end{tabular}

Table 4 Result

\begin{tabular}{cccc}
\hline \multirow{2}{*}{ User } & \multicolumn{3}{c}{ Respondent } \\
& Effectiveness & Efficiency & Satisfaction \\
\hline 1 & 50 & 80 & 80 \\
2 & 80 & 40 & 100 \\
3 & 100 & 75 & 100 \\
4 & 100 & 75 & 100 \\
5 & 80 & 80 & 95 \\
6 & 90 & 90 & 75 \\
7 & 100 & 100 & 100 \\
8 & 85 & 55 & 85 \\
9 & 85 & 50 & 85 \\
10 & 90 & 50 & 80 \\
Med & 87.5 & 75 & 90 \\
\hline
\end{tabular}

\section{Conclusions}

The conclusion of this study is that usability of a system is very important, the results of usability calculations in this study are effects 87.5, efficiency 75 and satisfaction 90 . The usability calculation results state that the system is in good category because the median results are above average. It's just that there are a number of features that are not yet available on this system such as a Masthead. Footers, Message Boxes and Windows Pop-ups, downloads and forums. 


\section{REFERENCES}

[1] Soebagio, "Analisis Kebijakan Pemanfaatan Ruang Pesisir dan Laut Kepulauan Seribu dalam Meningkatkan Pendapatan Masyarakat Melalui Kegiatan Budaya Perikanan Dan Pariwisata," Institut Pertanian Bogor, Bogor, 2005.

[2] L. Hakim, "Penentuan Zona Potensial Pariwisata Bahari di Pesisir Pantai Selatan Pulau Lombok NTB dengan Menggunakan Sistem Informasi Geografis (SIG)," Institut Pertanian Bogor, Bogor, 2007.

[3] A. Antagori, "Sistem Informasi Pariwisata dan Kebudayaan Kabupaten Bogor.," Universitas Pamulang, Pamulang, 2017.

[4] H. Taulay, "Pengembangan Sistem Pendukung Keputusan Pariwisata Kabupaten Kepulauan Talaud Berbasis Web," Institut Pertanian Bogor, Bogor, 2015.

[5] H. Hadi, "Rekayasa Kebergunaan Pada Sistem Informasi Kehumasan IPB.," Institut Pertanian Bogor, Bogor, 2010.

[6] Thoyyibah, "Prototype Sistem Berbasis Pengetahuan Pada Bibit Kelapa Sawit Menggunakan Pendekatan Usability Engineering,” Institut Pertanian Bogor, Bogor, 2014.

[7] D. Mayhew, The Usability Engineering Lifecycle., University California: Morgan Kaufhan Publishers, 1999.

[8] W. Hidayat, H. Radis and U. Efendi, "Penerapan Metode Usability Testing dan Evaluasi Situs Web Pemerintahan Kota Prabumulih," Jurnal Teknik Informatika Universitas Bina Darma Palembang, 2014.

[9] W. Handriwidjojo and L. Ernawati , "Pengukuran Tingkat Ketergunaan (Usability) Sistem Informasi Keuangan Studi Kasus: Duta Wacana Internal Transaction (DuWit)," Jurnal Informatika dan Sistem Informasi, vol. 2, no. 1:2460-1306, 2016.

[10] J. Nielsen, "Usability 101: Introduction to usability," Alertbox, 2012. [Online]. Available: http://www.nngroup.com/articles/usability-101-introduction-to-usability/. [Access: 17 May 2019].

[11] P. Edwards, P. Moloney, J. Jacko and F. Sainfort, "Evaluating Usability Of Commercial Electronic Health Record: A Case Study," Human Computer Studies Jurnal, pp. 718-728, 2008.

[12] H. Hafit, F. Razak and H. Haron, "Usability Testing with Children: What We Have Overlooked.," Human Computer Interaction Journal, pp. 147-150, 2011.

[13] W. Barendregt, M. Bekker and M. Speerstra, "Emprical Evaluation of Usability and Fun In Computer Games for Children," Human Computer Interaction Journal, pp. 705-708, 2003.

[14] A. Abran , A. Khelifi and W. Suryn, ". Usability Meaning and Interpretations in ISO Standards,” Software Quality Journal:, pp. 323-336, 2003.

[15] N. Diah , M. Ismail , S. Ahmad and M. Dahari, "Usability Testing for Educational Computer Game Using Observation Method," Computer and Mathematical Science Journal, vol. 1, pp. 4244-5651, 2010.

[16] J. Chung, N. Park, H. Wang, J. Fulk and M. McLaughlin, "Age Differences in Perceptions of Online Cummunity Participation Among Non-Users: An Extension of The Technology Acceptance Model," Computer in Human Behaviour Journal., vol. 26, pp. 1674-1684, 2010.

[17] W. Galitz, The Essential Guide to User Interface Design : An Introduction to GUI Design Principle and Techniques., Canada: John, 2007. 